\title{
From Their Bread to Their Bed: Commensality, Intermarriage, and Idolatry in Tannaitic Literature*
}

\author{
JORDAN D. ROSENBLUM \\ University of Wisconsin-Madison
}

\begin{abstract}
In the tannaitic corpus, a novel innovation appears: sharing bread is understood to lead to sharing a bed. As such, the Tannaim problematise and marginalise commensal interactions between Jews and non-Jews. In several instances, commensality with non-Jews is equated with idolatry, the binary opposite of Jewishness in rabbinic literature. While this connection is absent from Hebrew Bible texts and, at best, inchoate in a handful of Second Temple period sources, it is explicit in later amoraic literature. This article explores the gap between these corpora: tannaitic literature, in which we first encounter the rabbinic connection between bread and bed.
\end{abstract}

$\mathrm{T}$ he connection between food and sex-between bread and bed-is neither a modern nor a unique phenomenon. ${ }^{1}$ Further, the association between commensality and conjugal relations-between their bread and their bed-is affirmed by numerous cross-cultural studies. As Hasia Diner remarks: 'Put bluntly, the person with whom one cannot eat (and whose food cannot be consumed) is often the same person with whom sexual relations must be avoided.' 2 To share a table allows for the possibility (if not the probability) of

\footnotetext{
* An earlier version of this paper was delivered at the special meeting of the Philadelphia Seminar on Christian Origins at the Society of Biblical Literature Conference in Boston, MA on 21 November 2008. I thank the participants for their useful feedback. I would also like to acknowledge the insightful suggestions made by Gregg Gardner and the anonymous reviewer for $J J S$. Revisions of this article were completed during my tenure as a Starr Fellow at the Center for Jewish Studies at Harvard University, whose support I gratefully acknowledge.

${ }^{1}$ Ancient and medieval authors routinely connected the two appetites for food and sex. For references and discussion, see April Harper, "The Food of Love": Illicit Feasting, Food Imagery and Adultery in Old French Literature', in Medieval Sexuality: A Casebook, ed. April Harper and Caroline Proctor, pp. 81-97 (Routledge, New York, 2008). Further, cross-culturally, verbs of consumption are also utilised to refer to copulation. See Jeremy MacClancy, Consuming Culture: Why You Eat What You Eat (Henry Holt and Company, New York, 1993), pp. 70-71; Jack Goody, Cooking, Cuisine and Class: A Study in Comparative Sociology (Cambridge University Press, Cambridge, 1996), p. 114.

${ }^{2}$ Hasia R. Diner, Hungering for America: Italian, Irish, and Jewish Foodways in the Age of Migration (Harvard University Press, Cambridge, 2001), p. 4; see also Mary Douglas, 'Deciphering a Meal', in Food and Culture: A Reader, ed. Carole Counihan and Penny van Esterik, pp. 36-54 (Routledge, New York, 1997), p. 45; and below, n. 36. Further, marriage rites often include
} 
sharing a marriage.

Grasping the connection between bread and bed, the early rabbinic (tannaitic) ${ }^{3}$ movement sought to both problematise and marginalise commensality between Jews and Gentiles. ${ }^{4}$ Without explicit precedent in either the Hebrew Bible or Second Temple literature supporting their stance, ${ }^{5}$ the Tannaim 'find' support in biblical texts and - in their opinion-logical deductions. Although later amoraic ${ }^{6}$ texts will make this connection even more explicit, the Tannaim take the first steps towards prohibiting a practice that they are, at best, wary of: partaking of 'their bread'.?

\section{Methodology}

Before proceeding further, it is important to make three brief methodological remarks. First, I confine myself to the tannaitic corpus. Redacted roughly in third century CE Roman Palestine, these texts represent the earliest strata of rabbinic texts and, as such, provide us a glimpse at the nascent rabbinic movement. Scholars too often conflate tannaitic and amoraic material. In the process, temporal, geographical, cultural, and historical differences are glossed over, painting a picture of a landscape that never was. While amoraic texts offer several fascinating data about commensality and community, our gaze in this article shall remain on the tannaitic corpus, in which the rabbinic

elaborate feasting, wherein the meal serves to connect the families of the bride and groom. This connection remains in English, as the word 'bridal' originates from the Middle English root for 'bride' and 'ale-drinking', meaning the wedding feast. For an anthropological discussion, see Peter Farb and George Armelagos, Consuming Passions: The Anthropology of Eating (Houghton Mifflin, Boston, 1980), pp. 81-82 (on cross-cultural observations between food and sex in general, see pp. 82-90).

3 The Tannaim (singular: Tanna) lived from 70 CE to roughly 250 CE in Roman Palestine. I discuss the Tannaim further, below.

4 This is in line with a broader trend. In short, during a time a time when the boundaries between Jews and non-Jews begins to be viewed as religious rather than ethnic, Jewish regulations relating to a variety of social activities, commensality in particular, become increasingly fraught with tension. On this phenomenon in general, see Shaye J. D. Cohen, The Beginnings of Jewishness: Boundaries, Varieties, Uncertainties (University of California Press, Berkeley and Los Angeles, 2000), pp. 241-262. For a recent reassessment of Cohen's approach, see Steve Mason, 'Jews, Judaeans, Judaizing, Judaism: Problems of Categorization in Ancient History', JSJ 38/4-5 (2007), pp. 457-512, especially pp. 494 495, 505-510. On this phenomenon in regard to commensality, see Jordan D. Rosenblum, Food and Identity in Early Rabbinic Judaism (Cambridge University Press, Cambridge, 2010); Jordan D. Rosenblum, 'Kosher Olive Oil in Antiquity Reconsidered', JSJ 40/3 (2009), pp. 356-365.

5 On the pre-tannaitic evidence for commensality restrictions, see Rosenblum, Food and Identity, pp. 36-45. Although the references discussed therein reflect a growing apprehension concerning sharing a table with a non-Israelite/Jew, no text explicitly prevents such discourse on the grounds that such practices would lead from bread to bed. One could suggest that such an understanding is implied in a few Second Temple-period texts (e.g. Jubilees 22:16; Letter of Aristeas $139,142)$; however, such a reading would require conjecture that is neither definitive nor, in my opinion, convincing.

6 The Amoraim (singular: Amora) lived from roughly $250 \mathrm{CE}$ to $500 \mathrm{CE}$ in both Palestine and Babylonia.

7 mAvod. Zar. 2:6 (ed. Albeck 4:331) explicitly prohibits 'their bread', amongst a list of other non-Jewish foodstuffs. 
practice-based identity is often inchoate.

Second, I understand identity to be practice-based. By this I mean that rabbinic texts prescribe performed practices-bundled sets of doings and sayings - that index a constructed rabbinic identity. ${ }^{8}$ These practices establish social orders. ${ }^{9}$ Since ' $[p]$ ractices are not just the context, but also the site where the meanings of arranged entities are instituted', ${ }^{10}$ understanding identity as a category of practice provides a glimpse at the blueprint for a society. For example, American identity is, at least in part, derived from one's participation in certain commensal practices. To name a few: ingesting turkey, stuffing, cranberry sauce, etc. on the third Thursday of November ('Thanksgiving'); attending a barbecue, eating hotdogs, and watching fireworks on the fourth day of July ('Independence Day'); consuming apple pie; and eating 'peanuts and Cracker Jacks' at a baseball game. To engage in these bundled sets of social activities is, in some sense, to perform an American identity. Practices are the means by which a given person or group of persons is plugged into a matrix of social relations. This observation offers an avenue for crossing the theoretical chasm between social history and text. In short, when examining textual evidence, we must always remember that texts prescribe practices, and practices index identity. ${ }^{11}$

Third, the term 'idolatry' is understood to constitute a polemical and contested category. In a recent reassessment of this term in regard to the Hebrew Bible, Nathaniel Levtow argues that the term often tells readers more about the opinions of secondary scholarship rather than primary sources. Although biblical authors used 'force or discourse' in their parodies of non-Israelite icons, this is not necessarily to be equated with modern conceptions of 'idolatry', which presume 'an ontological critique of a so-called error in which a symbol is erroneously substituted for what it symbolises; in other words, the iconic "symbol" of a deity is "mistaken" for the referent deity itself." 12 That being said, the rabbinic texts discussed in this article seem to posit such a mistaken notion on the part of idolaters. However, this is most likely due to the fact that the icons and iconolatry discussed in rabbinic texts tend to be those that appear in the Hebrew Bible, and not in their contemporary world. ${ }^{13}$

\footnotetext{
${ }^{8}$ In understanding identity as practice-based, I am drawing on the theory of Theodore Schatzki. See Theodore R. Schatzki, The Site of the Social: A Philosophical Account of the Constitution of Social Life and Change (Pennsylvania State University Press, University Park, PA, 2002).

9 See Schatzki, Site of the Social, pp. 89-105.

${ }_{10}$ Schatzki, Site of the Social, p. 100.

11 See Rosenblum, Food and Identity, pp. 5-7.

12 Nathaniel B. Levtow, Images of Others: Iconic Politics in Ancient Israel, Biblical and Judaic Studies, vol. 11 (Eisenbrauns, Winona Lake, Indiana, 2008), pp. 16, 5-6; in general, see pp. 1-18.

13 I return to this final point later on in this article. See below, n. 34 .
} 


\section{Commensality, Intermarriage, and Idolatry ${ }^{14}$}

With these brief methodological considerations in mind, we can now turn to the topic at hand: commensality, intermarriage, and idolatry in tannaitic literature. Our survey of this topic first leads us to a particular commensal encounter that, at least from a rabbinic perspective, is fraught with problems: a Jew and non-Jew breaking bread at a Gentile wedding feast.

In Hebrew Bible texts, commensality between Israelites and non-Israelites at a wedding banquet does not appear to cause a serious issue. To prove this claim, one need look no further than the lengthy discussion of the riddles Samson tells to the Philistine guests at his seven-day wedding banquet, recounted in Judg. 14. Starting in the Second Temple period, however, intermarriage increasingly becomes an issue in Judean and Jewish texts, culminating in several prohibitions found in the Babylonian Talmud. ${ }^{15}$ For the Tannaim, a Gentile wedding banquet is the very type of commensal interaction that they wish to avoid. Since marriage affirms and reaffirms social relations and order, the meal that celebrates this occasion is clearly laden with meaning. ${ }^{16}$ To share this particular table is to plug oneself into a network of social relationships of which tannaitic texts appear, at best, wary.

This phenomenon is encountered in tAvod. Zar. 4:6, ${ }^{17}$ which states:

Rabbi Shimon ben Elazar says: 'Jews [literally: Israelites] outside of the Land [of Israel] are idolaters. ${ }^{18}$ How so? A non-Jew makes a [wedding] banquet for his $\operatorname{son}^{19}$ and goes and invites all of the Jews who live in his town. Even if they

14 Throughout this article, I focus on tannaitic commensality regulations in regard to interactions between Jews and non-Jews. The issues raised in these texts sometimes also apply to commensal encounters between rabbinic and non-rabbinic Jews. For the sake of clarity and focus, I have decided to leave the latter category out of my discussion. For an in-depth examination of tannaitic food regulations regarding commensal encounters between rabbinic and non-rabbinic Jews, see Rosenblum, Food and Identity, pp. 138-184.

15 See Cohen, Beginnings, pp. 241-262.

16 See Michael L. Satlow, Jewish Marriage in Antiquity (Princeton University Press, Princeton, 2001), p. 39.

17 Ed. Zuckermandel p. 466.

18 Some manuscripts read 'worship idols in purity'. This formulation also appears in Rabbi Shimon ben Elazar's statement in ADRN A26:6 (ed. Schechter p. 82) and in bAvod. Zar. 8a (where some manuscripts attribute the saying to Rabbi Ishmael; for references, see Zvi Aryeh Steinfeld, 'On the Prohibition of Eating with a Gentile', Sidra 5 (1988), pp. 131-148, Hebrew, p. $131 \mathrm{n}$. 1). Christine Hayes's understanding of these variants suggests that, even in these manuscript variants, purity itself does not play a part in tannaitic commensality regulations between Jews and non-Jews. See Christine Elizabeth Hayes, Between the Babylonian and Palestinian Talmuds: Accounting for Halakhic Difference in Selected Sugyot from Tractate Avodah Zarah (Oxford University Press, Oxford and New York, 1997), p. 161.

19 In some manuscripts of the Babylonian version of mAvod. Zar. 1:3 (ed. Albeck 4:325-326), the case of a 'non-Jew who makes a [wedding] banquet for his son' is included in a list of regulated private feast days in which economic and social interaction with Gentiles is prohibited. However, the omission of this phrase 'from the entire Palestinian branch of the Mishnah manuscripts, and its jarring interruption of the mishnah's style in the Babylonian branch, indicate that it is not original to the text of the mishnah but added to the Babylonian version at some point in the text's transmission history' (Hayes, Between, pp. 155-156). David Rosenthal attributes this tradition to a baraita found on bAvod. Zar. 14a. See David Rosenthal, Mishnah Avodah Zarah: Critical Edition Plus Introduction, 2 vols (Hebrew University Press, Jerusalem, 1981, Hebrew), pp. 58-59. 
eat and drink [only] their own [food and wine] and their own servant stands and serves them, they are idolaters, as it is said: 'And he will invite you and you will eat from his sacrifice' [Ex. 34:15]. ${ }^{20}$

Despite the fact that the food is clearly kosher, the banquet at which it is consumed is not. The concern here is commensal in nature, and not culinary; that is, with whom you eat, and not what you eat.

Discussing this pericope, Christine Hayes notes that Rabbi Shimon ben Elazar's statement should be understood as a moral, and not legal, pronouncement. ${ }^{21}$ Hayes's point is well-founded, as numerous tannaitic texts attest to the fact that commensality between Jews and Gentiles still occurs, even as it is increasingly marginalised. ${ }^{22}$ Even if Rabbi Shimon ben Elazar's statement does not carry the weight of law for other Tannaim, its implicit moral judgment against commensality with non-Jews is part of the emerging tannaitic discourse of table-based identity construction. In sum, a meal that was once acceptable is now socially problematic - if not necessarily legally transgressive - for tannaitic Jews to attend.

This accords with Sacha Stern's observation that, in rabbinic literature in general, all non-Jews are considered idolaters; as such, it seems reasonable to conclude that idolatry and non-Jewishness are coterminous. ${ }^{23}$ To eat with one is therefore to encounter, and to some extent to engage in, idolatry. Therefore, the food itself is insufficient to mark one as a Jew; because the perceived ramifications of commensality with Gentiles are so severe, one must not even attend the event, as doing so constitutes a social practice that threatens one's Jewish identity. It is for this reason that Rabbi Shimon ben Elazar morally stigmatises a social event that was previously permissible to attend. In short, now even if the food is kosher, the banquet itself is non-kosher. ${ }^{24}$

The fact that Rabbi Shimon ben Elazar uses a wedding banquet as an example of an intrinsically non-kosher meal is quite telling. As previously noted, marriage affirms and reaffirms social relations and order. Yet, intermarriage is

20 A baraita on bSan. 104b attributes to Rabbi Shimon ben Elazar the view that the Israelites were exiled because King Hezekiah allowed non-Israelites to eat at his table. Of course, this reading retrojects a later concern back into biblical times. For a rather positivistic attempt to read these texts together for social history, see Steinfeld, 'On the Prohibition', pp. 135-136.

21 Between, p. 160.

22 For a roughly contemporary analogue in Christian texts, see Canon 7 of the Council of Ancyra, a council that convened in Asia Minor in 314 CE. This canon punishes Christians who attend a Pagan feast, even if they bring and consume their own food. The problematisation and marginalisation of commensality between Jews and non-Jews as exemplified in the wedding banquet is a subject explored in later rabbinic texts (e.g. $A D R N$ A26:6, ed. Schechter p. 82, and bAvod. Zar. 8a). On these, and other relevant, texts, see David Moshe Freidenreich, Foreign Food: Restrictions on the Food of Members of Other Religions in Jewish, Christian, and Islamic Law (PhD diss., Columbia University, 2006), pp. 192-194; Hayes, Between, pp. 160-170; Steinfeld, 'On the Prohibition'; Sacha Stern, Jewish Identity in Early Rabbinic Writings (Brill, New York, 1994), pp. $151-152$.

23 Jewish Identity, p. 196.

24 Although $t$ Avod. Zar. 4:6 specifically refers to diaspora Jews, I concur with Freidenreich's interpretation, that 'the logic of this assertion applies equally with the Land of Israel, where a Jew might also receive a wedding invitation from a gentile neighbor or choose to attend such a celebration' (Foreign Food, p. 174). On the tannaitic notion that kashrut is a distinctly Jewish foodway, see Rosenblum, Food and Identity, pp. 68-73. 
not consistently prohibited in texts of the Hebrew Bible. ${ }^{25}$ Tannaitic literature occasionally expresses discomfort with this practice, but these texts are, as in the case of the wedding banquet described in tAvod. Zar. 4:6, implicit moral judgments, if not yet outright, unconditional bans. In this case, by problematising the diner instead of just the dinner, these regulations create practices that control social interactions. One can no longer engage in indiscriminate table-fellowship.

The problematisation of sharing a table and sharing a bed is found in a few tannaitic texts that, utilising the 'slippery slope' argument, connect commensality between Jews and non-Jews with intermarriage. Tacit within such statements is a condemnation of two practices with which the Tannaim disagree. A good example of this trend can be found in Mekilta d'Rabbi Shimon b. Yohai at Ex. 34:17. ${ }^{26}$ Commenting on Ex. 34:17, which proscribes making molten gods, the following statement appears: 'Thus, if one eats of their sacrifices, he will marry from amongst their daughters, and they will lead him astray and he will worship idols.' The connection between 'eating of their sacrifices'-a phrase that refers to both the meat itself and the sacrificial banquet at which that meat is ingested - and taking 'their daughters' as wives is understood in Mek. as the rationale behind Ex. 34:17's prohibition of molten gods.

In order to better understand this exegetical move, it is worth taking a moment to review Ex. 34:15-17.

Lest you make a covenant with the inhabitants of the land and they will whore after their gods and sacrifice to their gods and he will invite you and you will eat from his sacrifice. And when you take wives from amongst their daughters for your sons, their daughters will whore after their gods and will make your sons whore after their gods. As for molten gods, you shall not make them for yourselves.

This text should seem familiar, as $t$ Avod. Zar. 4:6 uses part of it as a proof-text. The concern here is against covenant-making with the Canaanites and ingesting sacrifices to other deities. ${ }^{27}$ While $t$ Avod. Zar. 4:6 uses Ex. 34:15 to indicate that willingly attending such a commensal interaction is akin to participating in the sacrifice itself, ${ }^{28} \mathrm{Mek}$. cleverly reweaves the fabric of the passage from Exodus into a tapestry that explicitly connects commensality between Jews and non-Jews with intermarriage, and both of these activities with idolatry. Reading Ex. 34:15-17 as a conditional statement, Mek. breaks these biblical verses into two segments: a protasis ('if one eats of their sacrifices') and an apodosis ('he will marry from amongst their daughters, and they will lead

\footnotetext{
25 See Saul M. Olyan, Rites and Rank: Hierarchy in the Biblical Representations of Cult (Princeton University Press, Princeton, 2000), pp. 81-90.

26 Ed. Epstein and Melamed p. 222.

27 This text also presumes that women are corruptors of men, leading men to whore after other gods - a clearly gendered terminology for idolatry. Although a discussion of the gendered aspects of this text in its biblical context lies beyond the purview of this article, it is important to note for our current purposes that this gendered terminology influences tannaitic literature, as we shall see again below.

28 See Hayes, Between, p. 161.
} 
him astray and he will worship idols'). ${ }^{29}$ This 'if/then' formulation logically suggests that separation at the table enacts and maintains a separate social identity - that of 'Us' (the monotheists) and 'Them' (the idolaters). This is part of a larger trend in rabbinic literature, detected by Sacha Stern, in which 'separateness or disassociation constitutes a form of social control, designed to protect the integrity of Israel as a distinctive social group. ${ }^{30}$ The borders of the collective whole of Israel in this context, therefore, are understood to begin at the borders of the table.

The connection between intermarriage and commensality with Gentiles is further found in Sifre Num. 131. ${ }^{31}$ In the midst of an expansion on the account in Num. 25:1-3 about how Moabite women seduced Israelite men, enticing them to worship Ba'al Pe'or, the text states:

She [a Moabite woman] would say to him [an Israelite man]: "Would you like to drink [some] wine? ${ }^{32}$ He would drink and the wine would burn within him and he would say: 'Listen to me [i.e. have intercourse with me]!' She would take out an image of Pe'or from under her bra and say to him: 'Rabbi, is it your desire that I listen to you? [If so, then] bow to this! ${ }^{33}$

The fact that Ba'al Pe'or is a biblical — not contemporary - deity does not seem to deter the Tannaim from making their larger point: ${ }^{34}$ namely, that sharing

${ }^{29}$ One could also read this text in Mek. as circular reasoning, as eating 'their sacrifices' can be considered idolatrous in and of itself. That being said, I believe that the main point of this passage is its broader application: namely, that commensality with non-Jews leads to idolatry.

30 Jewish Identity, p. 170. Stern goes on to write: 'Intermarriage, in particular, may be perceived as related to avoda zara [literally 'foreign worship', hence 'idolatry'], but it is equally considered a threat to Jewish identity; as we have seen, its prohibition implies a passionate commitment to preserving the integrity of Israel' (p. 170).

31 Ed. Horowitz p. 171.

32 This sentence is prefaced in Sifre Num. by a comment that 'the wine of non-Jews was not yet forbidden to Israel.' While I understand this statement to refer to commensality in general, it must be acknowledged that wine was a beverage explicitly associated with idolatry by the Tannaim. See Rosenblum, Food and Identity, pp. 81-83.

33 For later rabbinic parallels to this tale, see Satlow, Tasting, pp. 149-150. Joshua Levenson considers this text to be part of a pattern that emerges at the turn of the first century CE, in which sexual seduction is understood as an act of cultural seduction. Levenson's findings accord well with my own, since I am arguing that the sexual enticement in this passage reflects a broader tannaitic concern about the perils of un-controlled commensality. See Joshua Levenson, 'AnOther Woman: Joseph and Potiphar's Wife. Staging the Body Politic', JQR 87/3-4 (1997), pp. 269-301, especially $274 \mathrm{n}$. 17. Levenson acknowledges that his concept of cultural seduction is informed by David Stern, 'The Captive Woman: Hellenization, Greco-Roman Erotic Narrative, and Rabbinic Literature', Poetics Today 19/1 (1998), pp. 91-127.

34 See Seth Schwartz, Imperialism and Jewish Society, 200 BCE-640 CE (Princeton University Press, Princeton, 2001), p. 166. Contrast the positivistic interpretation of this text offered by Ephraim E. Urbach, 'The Rabbinical Laws of Idolatry in the Second and Third Centuries in the Light of Archaeological and Historical Facts', in Collected Writings in Jewish Studies, ed. Robert Brody and Moshe D. Herr, pp. 151-193 (Magness Press, Jerusalem, 1999), pp. 181-182. For a brief critique of Urbach's approach in this article in general, see Schwartz, Imperialism, p. 172. This is part of a general trend in rabbinic literature when discussing idolatry to interact with the world of the Hebrew Bible rather than with its own contemporary environment. Thus, this text, like many others, should be read as 'a discourse with texts, to be sure texts filtered through everyday life and experience, hence through the 'cultural space' in which they lived, but this cultural space has left surprisingly little imprint' on the document (Peter Schäfer, 'Jews and Gentiles in Yerushalmi Tractate Avodah Zarah', in The Talmud Yerushalmi and Graeco-Roman 
wine with Gentile women leads to an attempted seduction of Jewish men into idolatrous worship. On the one hand, this text is simply about the prohibition of Gentile wine on the grounds of idolatry. However, the sexualised nature of this interaction can be read to suggest that any commensal encounter with a non-Jewish woman might result in an inappropriate social relationship, from the tannaitic standpoint. ${ }^{35}$

Commenting on idolatry in general in rabbinic literature, Sacha Stern notes: 'Avoda zara [idolatry] is ... a defining metaphor of non-Jewishness, or even its embodiment. This is why in the context of intermarriage the avoidance of avoda zara and of non-Jewishness are virtually undistinguishable. ${ }^{36}$ Tannaitic texts that connect table-fellowship between Jews and non-Jews with idolatry via seduction by non-Jewish/Israelite women contribute to the blurring of the boundaries of which Stern speaks. The not-so-tacit question in these texts appears to be: if idolatry is the binary opposite of Jewishness, then how can a Jewish man share a table with a non-Jewish woman who could tempt him into such a practice? Sharing a table is therefore understood as the first step towards sharing a bed and, consequently, the first step down the slippery slope that leads to the embodiment of non-Jewishness: idolatry. The Amoraim later make this association even more concrete by providing an explicit rationale for certain rabbinically ordained food prohibitions: 'because of intermarriage'. ${ }^{37}$ By problematising commensality with non-Jews, the Tannaim seek to reinforce Jewish identity. With whom one eats is therefore seen as a practice that makes an active identity statement in the present, as well as an accurate predictor of one's identity in the future. Sitting apart at meals, to paraphrase Tacitus' observation about Jewish behaviour, ${ }^{38}$ is perceived in tannaitic literature to be a reliable method of preserving a distinct Jewish identity.

While tannaitic texts marginalise commensality with Gentiles, they still provide evidence for the possibility of such social interactions. Although the Tannaim introduce tensions and restrictions in regard to commensal encounters that are often unprecedented, these 'fences around the table'- to play on

Culture, Ed. Peter Schäfer, pp. 335-352, vol. 3, Mohr Siebeck, Tübingen, 2002, p. 351; in general, see pp. 346-352). Schäfer's comments refer specifically to the Palestinian Talmud, but they also apply to tannaitic literature.

35 This observation accords with Michael L. Satlow's argument that Palestinian rabbinic literature in general contains a stereotype that, '[s]exually speaking, women are trouble' ('Fictional Women: A Study in Stereotypes', in The Talmud Yerushalmi and Graeco-Roman Culture, ed. Peter Schäfer, pp. 225-243, vol. 3, Mohr Siebeck, Tübingen, 2002, p. 235).

36 Jewish Identity, pp. 196-197, original emphasis. This discomfort is not unique to tannaitic literature, as anthropologists have noted a cross-cultural connection between conjugal and commensal relations. In the words of Emiko Ohnuki-Tierney: 'Commensality and sexual union are the fibers that weave human relationships into a tapestry of culturally meaningful patterns' (Rice as Self: Japanese Identities through Time, Princeton University Press, Princeton, 1993, p. 119).

The fact that these fibres intersect at the table should not be surprising; we have continuously seen that the table is a locus for identity negotiation. Further, the table is also a locus for establishing power, as Caroline Walker Bynum persuasively argues in regard to medieval Christian women. See Caroline Walker Bynum, Holy Feast and Holy Fast: The Religious Significance of Food to Medieval Women (University of California Press, Berkeley and Los Angeles, 1988).

37 bAvod. Zar. $31 \mathrm{~b}$ and $35 \mathrm{~b}$ (also see $36 \mathrm{~b}$ ).

38 Commenting on what he perceives as a Jewish predilection towards separation, Tacitus remarks 'They sit apart at meals' (Historiae, 5.5.2). 
a rabbinic idiom ${ }^{39}$-are not impenetrable. Thus, these texts appear to employ what Michael Satlow refers to as 'persuasive rhetorics'. As this term implies, persuasive rhetorics promote normative practices without necessarily appealing to legal justifications. ${ }^{40}$ Applying this concept, mutatis mutandis, to the topic at hand helps to explain those tannaitic texts that problematise, but stop short of legally prohibiting, commensality with Gentiles. ${ }^{41}$ In these texts, the shared table is the first step down a slippery slope that leads to idolatry. As such, commensality with non-Jews is a social situation best avoided.

I would thus argue that the Tannaim are concerned with both foreign worship and foreigners. Tannaitic (and, especially, later amoraic) literature piggybacks rhetorics of persuasion against commensality with non-Jews upon legal rhetorics prohibiting idolatry. ${ }^{42}$ This principle also applies to Rabbi Shimon ben Elazar's moral condemnation of the non-Jewish wedding banquet in tAvod. Zar. 4:6. Costuming persuasive rhetoric in the guise of a legal rhetoric allows the Tannaim to marginalise commensality with Gentiles. By expanding laws about idolatry, drawing on assumptions about sexuality, and employing the 'slippery slope' principle, the Tannaim marginalise commensality with non-Jews and begin to prescribe social practices that result in separation at meals. With whom one eats becomes an even stronger statement of identity in tannaitic literature than in previous Judean and Jewish sources, as the fault line between 'Us' and 'Them' is ever increasingly located down the centre of the table.

\section{Commensality Regulations that Might Imply Idolatry}

In addition to the above commensality practices that specifically address intermarriage and idolatry, there is another tannaitic meal practice that - often more subtly or tacitly — establishes a distinctly Jewish identity through regulating commensal interactions with non-Jews: the institution of specific 'table talk'. I define the term 'table talk' rather broadly, as constituting all regulated formulae (i.e. blessings, meal prayers), structures (i.e. the Passover haggadah), topics (i.e. Torah), and genres (i.e. philosophical symposia) that prescribe words spoken around the table in a commensal setting. Table talk is a common feature in descriptions of Greek and Roman dining scenes. ${ }^{43}$ Since the food on a Jew's plate is often quite similar to that of a non-Jew in antiquity - usually consisting of grains, oil, and wine, the so-called Mediter-

\footnotetext{
39 E.g. $m$ Avot 1:1 (ed. Albeck 4:353).

40 See Tasting, p. 8. Satlow also defines 'legal rhetorics' as, 'rabbinic discussions of the law, their attempts to define transgressions, categorize them, and establish issues of liability' (Tasting, p. 8).

${ }^{41}$ Legal prohibitions do appear, however, in amoraic literature. An historical analogue can be found in Canon 50 from the early fourth century Council of Elvira, which prohibits Christians from engaging in commensality with Jews. See Freidenreich, Foreign Food, pp. 135-141.

42 This accords with a general trend in rabbinic literature, summarised by Stern, Jewish Identity, pp. 195-198.

43 See Dennis E. Smith, From Symposium to Eucharist: The Banquet in the Early Christian World (Fortress Press, Minneapolis, 2003), pp. 50-64.
} 
ranean triad ${ }^{44}$ - then the style and content of table talk may be the only distinguishing feature of many 'Jewish' meals. ${ }^{45}$ Tannaitic table talk provides interesting data for the discussion of commensality regulations. On the one hand, several texts introduce laws and practices that seemingly prevent this social intercourse, as we have already seen. On the other hand, other texts suggest that commensality with Gentiles can occur. Further, even those texts that do assume that Jews and non-Jews can share a table often utilise persuasive rhetoric that marginalise these social interactions.

Those texts that possibly suggest that commensality with non-Jews can occur discuss the role that non-Jews can or cannot play in the recitation of food blessings. For example, we learn that non-Jews do not count towards the prayer quorum (the minyan) necessary to recite grace after meals ${ }^{46}$ and that a Jew may respond 'amen' to the blessing in the name of God offered by a non-Jew. ${ }^{47}$ One could read these texts as descriptive and conclude that the Tannaim recognise the presence of non-Jews at the meal and are seeking to determine to what extent non-Jews can participate in table talk; one could argue that these texts are prescriptive and that the Tannaim seek to use table talk to marginalise or exclude non-Jews from the tannaitic table; finally, one could suggest some combination of these two opinions, or even another similar theory (for example, they are simply scholastic in nature). Although I prefer to read these texts as prescriptive, regardless of what stance one takes, by addressing the case of the non-Jew, these texts explicitly mark him as 'Other'. In doing so, the Tannaim use the 'Other' to define the 'Self' ${ }^{48}$ Therefore, even if these data point towards the inclusion of non-Jews at the tannaitic table, they are not perceived as full participants in table talk, a key commensal practice that marks tannaitic identity.

Non-Jewish participation in tannaitic commensality is especially problematised in mAvot 3:3:49

\footnotetext{
44 On the Mediterranean triad in antiquity, see Peter Garnsey, Food and Society in Classical Antiquity (Cambridge University Press, Cambridge and New York, 1999), pp. 12-21; for the modern history of the term (and concept), see John Dickie, Delizia!: The Epic History of the Italians and Their Food (Hodder \& Stoughton, London, 2007), pp. 302-305.

45 See David Kraemer, Jewish Eating and Identity Through the Ages (Routledge, New York, 2007), p. 73.

46 mBer. 7:1 (ed. Albeck 1:26). Some scholars speculate that a document at Qumran (4Q434) resembles the rabbinic formula for the version of grace after meals recited in the house of a mourner. For example, see Moshe Weinfeld, 'Grace After Meals in Qumran', JBL 111/3 (1992), pp. 427-440; Moshe Weinfeld and David Rolph Seely, '4Q434. 4QBarkhi Nafshi', in Qumran Cave 4. XX, Poetical and Liturgical Texts, Part 2, Discoveries of the Judean Desert 29, pp. 267286 (Clarendon Press, Oxford, 1999). If this interpretation is correct-and it seems more like conjecture than substantiated fact - then there is a pre-tannaitic precedent for this liturgical formula.

47 tBer. 5:21 (ed. Lieberman 1:28). This is a general statement in Tosefta and does not apply solely to blessings over food. However, its context in situ in the midst of a discussion of foodbased blessings suggests its applicability to the subject at hand.

48 As Stern observes, this type of rhetorical move 'suggests a dialectical relationship of self and other where the other serves no other purpose, and has no other raison d'être, but to define and enhance the essence of self' (Jewish Identity, p. 46).

49 Ed. Albeck 4:363-364.
} 
Rabbi Shimon said: '[If] three [men] have eaten on one table and they did not speak words of Torah, it is as if they had eaten of the sacrifices to dead [idols], as it is said: "For all tables are filled with vomit and filth without God." ${ }^{50}$ But three [men] who ate on one table and spoke words of Torah, it is as if they had eaten from the tables of God Blessed-Be-He, as it is said: "And he said to me: 'This is the table that is before Yhwh.',, 51

Torah-based table talk is one of the social practices that mark the difference between an idolatrous sacrifice and 'proper' sacrifice to Yhwh. mAvot 3:3 contains the common tannaitic connection between the table of the Jewish home and the table (i.e. the altar) of the Jewish Temple. Without proper table talk, the meal devolves into idolatry. While I may be reading too much into this text, which is the only tannaitic reference that explicitly draws this connection, this conclusion does not seem far off base, especially in light of some of the texts that we have already discussed.

Tannaitic legal and persuasive rhetoric suggest a growing concern regarding commensality with Gentiles. Non-Jews are marked as the 'Other' both through legal discussions about their ability to participate in meal-based liturgy and through persuasive rhetoric that concerns their inability to participate in Torah-based (and hence, non-idolatrous) discourse. As the table is an important locus of identity negotiation, eating with one who can both fully participate and is knowledgeable in tannaitic table talk allows Jews to secure their Jewish identity. In short, in the tannaitic corpus, commensality with Gentiles has become a practice best avoided by Jews.

\section{Conclusions}

Commensality regulations are practices, bundled sets of doing and sayings, that index membership in communal bodies, essentially dividing the world into two distinct categories: those with whom you eat, and those with whom you do not eat. By connecting commensality between Jews and non-Jews with intermarriage and idolatry, the Tannaim turn the biological necessity of ingesting calories into cultural acts of identity negotiation. Indiscriminate tablefellowship is now seen as a slippery slope, which inevitably leads to the binary opposite of Judaism: idolatry. Throughout, however, tannaitic commensal regulations include accommodations allowing for controlled interactions with non-Jews. ${ }^{52}$ Yet, while Jews and Gentiles are not completely separated,

50 This is a clever rereading of Isa. 28:8. In the biblical verse, the final words are 'without a [clean] place'. The Hebrew word for 'place' (maqom) is one of the rabbinic terms for God. Through decontextualisation and anachronism, the rabbinic author crafts a 'proof-text' without changing a single word.

51 Ezek. 41:22. mAvot 3:2 (ed. Albeck 4:363) also mentions the importance of two who sit together discussing 'words of Torah', but does not explicitly set the proverbial scene at a dining table.

52 This conclusion accords with the recent work of several scholars who suggest that the rabbis create accommodations so as to allow for a variety of controlled social and economic interactions with non-Jews. For example, see Yaron Z. Eliav, 'Viewing the Sculptural Environment: Shaping the Second Commandment', in The Talmud Yerushalmi and Graeco-Roman Culture, ed. Peter Schäfer, pp. 411-433, vol. 3 (Mohr Siebeck, Tübingen, 2002); Schwartz, Imperialism, especially pp. $162-176$. 
commensal interactions become more problematised and marginalised, as the rabbinic meal becomes increasingly laden with social practices that construct Jewishness. 